\title{
Experimental Study on Micro-Biological Degradation of 1,3,5-TMB in Groundwater
}

\author{
Dunyu Lv and Chu Yu
}

\begin{abstract}
TMB (trimethylbenzene) has been considered as a priority pollutant by several environmental agencies due to its high toxicity, carcinogenicity and mutagenic activity. Two bacteria with ability of degrading 1,3,5-TMB were isolated from crude oil contaminated soil. The optimal pH value and temperature for the growth of these bacteria were 7.0 and $30^{\circ} \mathrm{C}$. 1,3,5-TMB was used as sole carbon and energy source by both strains. Strain $A$ was identified as Staphylococcus sciuri and strain $C$ was Microbacterium schleiferi, both of which were facultative anaerobic bacteria. 1,3,5-TMB was degraded by strain $C$ with efficiency of $41.2 \pm 1.8 \%$. The bacteria offered new source for biodegradation of BTEX and bioremediation of oil-contaminated soil and groundwater.
\end{abstract}

Index Terms-1,3,5-TMB, biodegradation, facultative anaerobic strain, Staphylococcus sciuri, Microbacterium schleiferi.

\section{INTRODUCTION}

1,3,5-TMB (trimethylbenzene) is one of primary constituents of petroleum and considered to be priority pollutant due to the high toxicity, carcinogenicity and mutagenic activity. Contamination of groundwater with the benzene compounds is difficult to be remedied because they are relatively water-insoluble and can diffuse rapidly once introduced into aquifers [1], [2].

One of the most attractive means to remove $1,3,5-\mathrm{TMB}$ is bioremediation. Despite of the toxicity and persistence, this kind of compounds can be degraded and utilized by many microorganisms as a sole source of carbon and energy [3]. Numerous studies have focused on the biodegradation of 1,3,5-TMB under various aerobic conditions.

The microbial metabolism patterns of $1,3,5$-TMB was highly diverse[4]-[7]. The research aimed to screen strains that are able to degrade 1,3,5-TMB under both aerobic and anaerobic conditions.

\section{MATERIALS AND METHODS}

\section{A. Culture Media and Growth Conditions}

The experimental bacteria were grown in $100-\mathrm{mL}$ shake flasks with $50-\mathrm{mL}$ mineral salts (MS) liquid culture medium. The MS liquid medium contained $0.42 \mathrm{~g} \mathrm{NaNO}, 0.27 \mathrm{~g}$

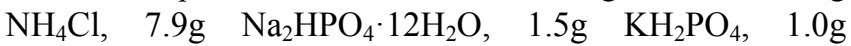
$\mathrm{MgSO}_{4} \cdot 7 \mathrm{H}_{2} \mathrm{O}, 1.2 \mathrm{~mL}$ trace elements solution and $1 \mathrm{~L}$

Manuscript received April 16, 2013; revised July 8, 2013.

The authors are with The Institute of Hydrogeology and Environmental Geology, Shijiazhuang 050061, China (e-mail: lvdunyu@hotmail.com, yuchu_1112@163.com) distilled water, $\mathrm{pH}$ 7.0. Trace elements solution without carbon contained $2.14 \mathrm{~g} / \mathrm{L} \mathrm{ZnCl} 2,2.5 \mathrm{~g} / \mathrm{L} \mathrm{MnCl}_{2} \cdot 4 \mathrm{H}_{2} \mathrm{O}, 0.3$ $\mathrm{g} / \mathrm{L} \quad \mathrm{CoCl}_{2} \cdot 6 \mathrm{H}_{2} \mathrm{O}, \quad 0.2 \quad \mathrm{~g} / \mathrm{L} \quad \mathrm{CuCl}_{2} \cdot 2 \mathrm{H}_{2} \mathrm{O}, \quad 0.4 \mathrm{~g} / \mathrm{L}$ $\mathrm{NaMoO}_{4} \cdot 2 \mathrm{H}_{2} \mathrm{O}, 4.5 \mathrm{~g} / \mathrm{L} \mathrm{CaCl} 2 \cdot 2 \mathrm{H}_{2} \mathrm{O}, 2.9 \mathrm{~g} / \mathrm{L} \mathrm{FeCl} \cdot 6 \mathrm{H}_{2} \mathrm{O}$, $1.0 \mathrm{~g} / \mathrm{L} \mathrm{H}_{3} \mathrm{BO}_{3}$, and $0.1 \mathrm{~g} / \mathrm{L} \mathrm{KI}$. For agar solid medium, $20 \mathrm{~g} / \mathrm{L}$ agar was further added. After moist heat sterilization for $15 \mathrm{~min}, 1,3,5-\mathrm{TMB}$ was added to the liquid medium as the sole carbon and energy source. All bacterial were cultured at $30^{\circ} \mathrm{C} \pm 2{ }^{\circ} \mathrm{C}$ with $150 \mathrm{r} /$ min shaking. When choosing the cultivation temperature and $\mathrm{pH}$, the $\mathrm{pH}$ value of soil sample solutions and the ambient temperature of samples collected were taken into account.

The 1,3,5-TMB used was analytical grade. All other reagents were of the highest grade commercially available. Aqueous stock solutions for each of these compounds were prepared in shake flasks sealed with Teflon-coated rubber stoppers and aluminum crimps.

\section{B. Bacterial Domestication, Screening and Isolation}

The experimental bacteria were isolated from soil samples which were harvested from contaminated crude oil at an oilfield. The field moist soil samples were stored at $4^{\circ} \mathrm{C}$ for further experiments.

Soil samples $(5 \mathrm{~g})$ were first washed with distilled water and centrifuged to remove most of the particles. Then the suspended samples $(5 \mathrm{~g})$ were collected in $150-\mathrm{mL}$ shake flasks, with sterilized MS medium $(50 \mathrm{~mL})$ and a headspace of about 100-mL with gas/liquid ratio of 2:1, and supplemented with $0.472 \mathrm{~g} / \mathrm{L}$ sodium succinate, $12.5 \mu \mathrm{L}$ 1,3,5-TMB. An aliquot of $1 \mathrm{~mL}$ bacterial suspension was sub-cultured to fresh medium every two to four days, with the concentration of 1,3,5-TMB increasing from $12.5 \mu \mathrm{L}$ to $50 \mu \mathrm{L}$ and that of sodium succinate decreasing from 0.472 $\mathrm{g} / \mathrm{L}$ to $0 \mathrm{~g} / \mathrm{L}$. After four cycles, some bacteria were domesticated to use 1,3,5-TMB as only C-source. From this bacterial suspension, a serial dilution method was used for bacterial isolation. The gas-liquid was controlled at a ratio of 2:1, because facultative anaerobes could be selected by limiting microbial oxygen consumption.

The isolated bacterial strains which were observed higher ability to grow on agar medium were selected for further studies. Colonies formed on the plates were purified by agar plate dilution method. Strains were routinely maintained on agar MS medium slants at $4^{\circ} \mathrm{C}$ in the fridge and were transferred into fresh MS liquid medium once a month.

\section{Bacterial Identification}

The identification of strains of two bacteria with $1,3,5$-TMB biodegradation ability was initially preceded on the basis of colony morphology, phenotype, physio-biochemical traits. Cell morphology and cell 
motility were examined by phase-contrast light microscopy. Gram-staining, catalase testing and other classical tests were performed according to the eighth edition of Bergey's Manual of Determinative Bacteriology. Anaerobic growth was investigated by incubation in the presence and absence of oxygen using the Anaero cult system (Merck). Further analysis of $16 \mathrm{~S}$ rDNA sequence was used for molecular identification.

Purified bacterial strains were grown in MS medium, and genomic DNAs were extracted using a genomic DNA purification kit (Promega) in accordance with the manufacturer's instructions. Amplification reaction was performed on Master cyclerepgradient S PCR system (Eppendorf AG, Germany) using primers P1 (5'-AGAGTTTGATCCTGGCTCAG-3') and P2 (5'GGTTACCTTGTTACGACTT-3'). Each PCR mixture (50 $\mu \mathrm{L})$ was composed of $20 \mathrm{mM}$ Tris- $\mathrm{HCl}(\mathrm{pH} \mathrm{8.0)}, 0.5 \mu \mathrm{l}$ MP1 and P2, deoxynucleoside triphosphate at a concentration of $200 \mu \mathrm{M}$, each primer at a concentration of $0.1 \mu \mathrm{g}$ template DNA, and $2 \mathrm{U}$ of Taq DNA polymerase. The amplification program consisted of an initial denaturationat $94^{\circ} \mathrm{C}$ for $5 \mathrm{~min} ; 38$ cycles of $94^{\circ} \mathrm{C}$ for $30 \mathrm{~s}$, $61-65^{\circ} \mathrm{C}$ for $30 \mathrm{~s}$, and $72^{\circ} \mathrm{C}$ for $60 \mathrm{~s}$ and finally, an additional extension step at $72^{\circ} \mathrm{C}$ for $10 \mathrm{~min}$. Amplification products were subjected to gel electrophoresis in $1 \%$ agarose, followed by ethidium bromide staining. DNA patterns were visually analyzed after photography by EC3 600 Imaging System (UVP, LLC, US). PCR amplification products purification and sequencing with the Applied Bio systems 373AAutomated DNA Sequencer was done by Shanghai Invitrogen Biotechnology Co., Ltd. and sequences were aligned using BLAST+2.2.22 program available in NCBI website.

\section{Optimum Grow Conditions}

The optimum $\mathrm{pH}$ was determined, with $\mathrm{pH}$ values adjusted to 4, 5, 7, 9 with $\mathrm{HCl}(1 \mathrm{M})$ or $\mathrm{NaHCO}_{3}(1 \mathrm{M})$, in $200 \mu \mathrm{L}$ bacteria cultures growing in $50 \mathrm{~mL}$ MS medium in the presence of $50 \mu \mathrm{L}$ (about $879 \mathrm{mg} / \mathrm{L}$ ) 1,3,5-TMB. The optimum temperature was determined at different incubation temperature conditions $\left(4,15,30\right.$, and $40^{\circ} \mathrm{C}$ ) assessed in triplicate incubation series. Cell growth was monitored once every 24 hours by measuring the optical density (OD) of culture at $600 \mathrm{~nm}$ with $722 \mathrm{~N}$ visible spectrophotometer (Shanghai Jinpeng Analysis Instrument Co., Ltd, China).

\section{E. Analytical Methods}

The concentration of 1,3,5-TMB was measured by GC analysis of the headspace [8], [9]. Controls containing no microorganism were also assayed to compensate the abiotic loss. The compound consumed was determined by the comparison of gas phase 1,3,5-TMB concentration in a sample flask with that in a control flask. All samples, irrespective of the incubation temperature of the cultures, were equilibrated at $60^{\circ} \mathrm{C}$ for 30 mins before $\mathrm{GC}$ analysis. After $500 \mu \mathrm{L}$ of headspace was withdrawn by a $5 \mathrm{~mL}$ Hamilton gas-tight syringe, it was injected into a gas chromatograph (HP 5890N) equipped with an HP-5capillary column and a flame-ionization detector [10]. Chromatography was accomplished over8mins using an oven temperature of $40^{\circ} \mathrm{C}$ for 1 min followed by a $6^{\circ} \mathrm{C}$ $/ \mathrm{min}$ rise up to $80^{\circ} \mathrm{C}$ and held for $4 \mathrm{mins}$ at this temperature. The injector and detector temperatures were set to 220 and $250^{\circ} \mathrm{C}$, respectively. Nitrogen was used as a carrier gas at a flow rate of $2 \mathrm{~mL} / \mathrm{min}$. 1,3,5-TMB was separated with retention time of 10.3 mins, respectively. Detection limits ranged from 8.67 to $13.85 \mu \mathrm{g} / \mathrm{L}$ and recovery rates from 85.3 to $102.6 \%$.

\section{F. Biodegradation of 1,3,5-TMB}

After strains pre-incubated for 36 hours, bacterial suspension was diluted to the same OD value with sterile water for batch experiments. The experiments were conducted using $100 \mathrm{~mL}$ shake flasks, sealed with Teflon-lined caps and aluminum crimps, containing $50 \mu \mathrm{L}$ bacterial cultures, $50 \mathrm{~mL}$ medium and $10 \mu \mathrm{L}$ 1,3,5-TMB individually, there was no additional carbon source added. The compounds were injected as pure stock with a $10-\mu \mathrm{L}$ syringe. The initial concentration of 1,3,5-TMB was approximately $175.7 \mathrm{mg} / \mathrm{L}$. All the experiments were conducted at $30^{\circ} \mathrm{C}, \mathrm{pH} 7.0$ in a shaking incubator at 200 $\mathrm{r} / \mathrm{min}$.

Three replicates were used for each batch. Sterile controls, prepared by autoclaving for $15 \mathrm{mins}$ at $120^{\circ} \mathrm{C}$, were set to discern volatilization and adsorption losses of 1,3,5-TMB. The cultures were routinely examined by CPH-500E phase contrast microscope (Shanghai Changfang Optical instrument Co., Ltd, China) to ensure the absence of bacterial contamination [11]. Biodegradation was assessed by comparing the disappearance of $1,3,5-\mathrm{TMB}$ in samples and controls over time. The biodegradation of 1,3,5-TMB was measured after 72 hours.

\section{RESULTS AND DISCUSSION}

\section{A. Identification of the Degradation Bacteria}

The indigenous bacteria which were capable of utilizing $1,3,5-\mathrm{TMB}$ as the sole source of carbon and energy were isolated from polluted soil. Strain A and C were selected for further studies because it showed better growth on agar plate with 1,3,5-TMB. Their physic-biochemical characters were shown in Table I.

Colonies of strain A were circular, slightly protruding, jagged, opaque, glossy and creamy white with a maximum colony diameter of $2 \mathrm{~mm}$ after 72 hours (photograph not shown). Growth occurred at $4{ }^{\circ} \mathrm{C}$ and $41^{\circ} \mathrm{C}$. Strain A was found to be facultative anaerobic, gram-positive, catalase-positive, oxidase-negative and colorless. The cells were shown to be round when visualized by phase contrast microscopy. Nonmotile cells generally occurred in groups. This morphologic appearance fitted the original description of Staphylococcusspp in the eighth edition of Bergey's Manual of Determinative Bacteriology.

Colonies of strain C were circular, slightly sunken, smooth, semi opaque, glossy and yellow pigmented with a maximum colony diameter of $1.5 \mathrm{~mm}$ after 72 hours. Growth occurred at $4{ }^{\circ} \mathrm{C}$ and $41^{\circ} \mathrm{C}$. Strain $\mathrm{C}$ was found to be facultative anaerobic, gram-positive, catalase-positive, oxidase-positive, and yellow-pigmented. The cells were shown to be rod-shaped when visualized. This morphologic 
appearance fitted the original description of Microbacteriumspp in the eighth edition of Bergey's Manual of Determinative Bacteriology.

TABLE I: DIFFERENTIAL MORPHOLOGICAL AND PHYSIC-BIOCHEMICAL Characteristics of Strain A AND C (+, Positive; -, Negative)

\begin{tabular}{|c|c|c|}
\hline Characteristic & Strain A & Strain C \\
\hline Cell shape & round & rod-shaped \\
\hline Motility & immobility & immobility \\
\hline Pigment & no pigment & yellowish \\
\hline Growth at $4{ }^{\circ} \mathrm{C}$ & + & + \\
\hline Growth at $41^{\circ} \mathrm{C}$ & + & + \\
\hline Growth at $60{ }^{\circ} \mathrm{C}$ & - & + \\
\hline Gram staining & + & + \\
\hline Glucose & + & + \\
\hline Fructose & + & + \\
\hline Sucrose & + & + \\
\hline Maltose & - & + \\
\hline Gelatin liquefaction & + & + \\
\hline Nitrate reduction & + & + \\
\hline Oxidase & + & + \\
\hline Catalase & + & + \\
\hline Aerobism & + & + \\
\hline & + & + \\
\hline & + & + \\
\hline & + & + \\
\hline & + & + \\
\hline
\end{tabular}

\section{B. Environmental Factors on the Growth of Strains}

The temperature influence on the metabolic activity differed between strain $\mathrm{A}$ and $\mathrm{C}$, as seen in Fig. 1. At $4^{\circ} \mathrm{C}$ the growth of both stains was considerably slow. Comparing the temperature effect results, strain A adjusted itself less quickly than strain C. After 48 hours log phase, strain A stepped into exponential growth phase and OD600nm increased rapidly. Both strains grew at temperature $15-40^{\circ} \mathrm{C}$ with $1,3,5-\mathrm{TMB}$ as carbon and energy source. The temperature at $30^{\circ} \mathrm{C}$ was most favorable for the growth of both strains.

The influence of $\mathrm{pH}$ on bacterial growth was shown in Fig. 2. The growth rate increased with the increase of $\mathrm{pH}$ between 4.0 and 9.0. Both strains grew well at $\mathrm{pH}$ at 7.0 and 9.0; however, the bacteria could adapt more quickly and grow steadier at $\mathrm{pH} 7.0$.

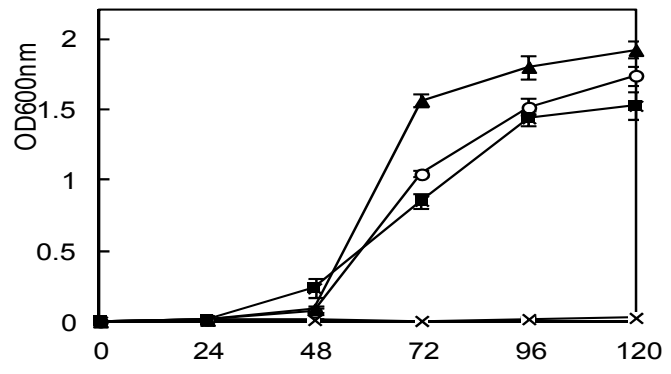

(a) Incubation time (hours)

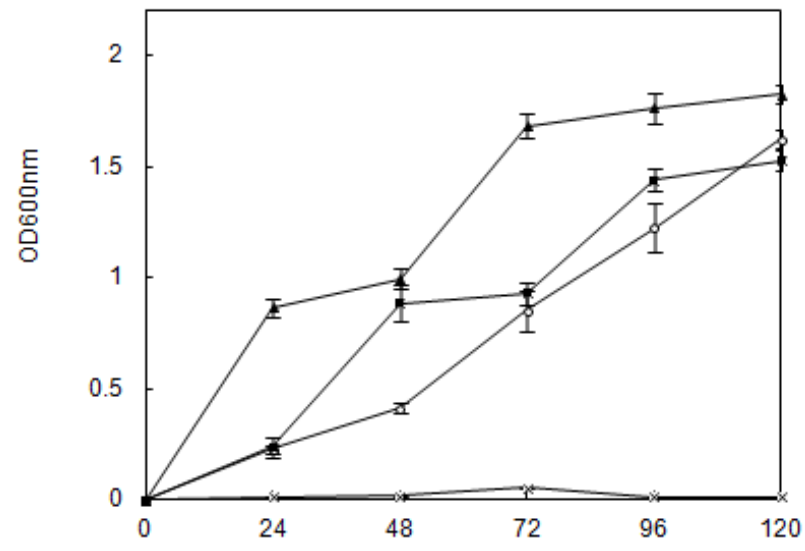

(b)

Incubation time (hours)

Fig. 1. Effects of temperature on bacterial growth during a 120-hour incubation period. (a), strain A; (b), strain $\mathrm{C} ; \times, 4^{\circ} \mathrm{C} ; \circ, 15^{\circ} \mathrm{C} ; \boldsymbol{\Delta}, 30^{\circ} \mathrm{C}$; , $40^{\circ} \mathrm{C}$. Error bars represent standard deviation of results (may be covered by symbols)

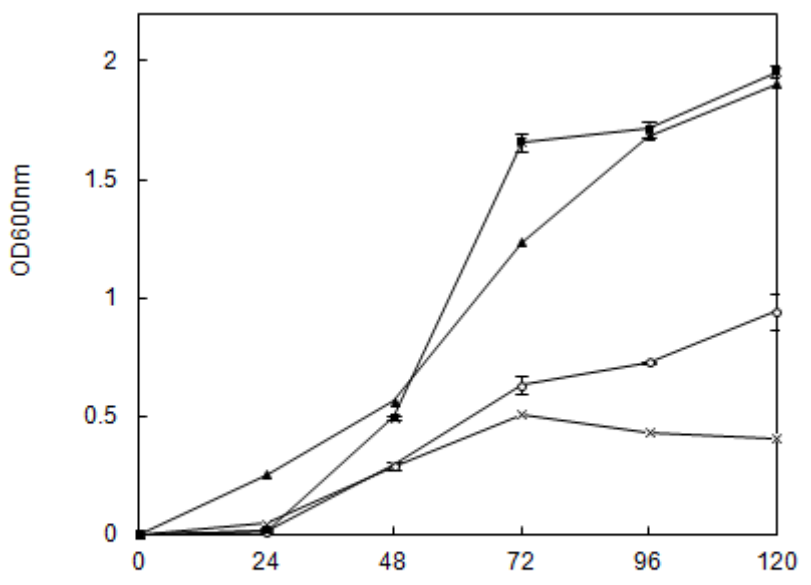

(a)

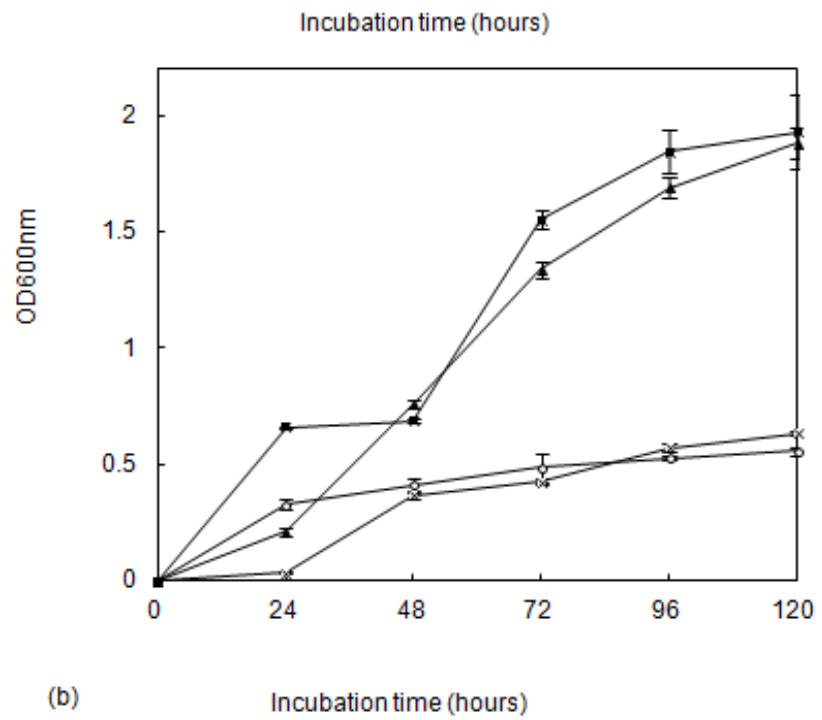

Fig. 2. Effects of $\mathrm{pH}$ on bacterial growth during a 120-hour incubation period. (a), strain $\mathrm{A}$; (b), strain $\mathrm{C} ; \times, \mathrm{pH}=4 ; \circ, \mathrm{pH}=5 ; \boldsymbol{\Delta}, \mathrm{pH}=7 ; \boldsymbol{\varpi}, \mathrm{pH}=9$.

Error bars represent standard deviation of results (may be covered by symbols)

\section{Degradation of 1,3,5-TMB}

The two isolated strains were examined for the ability to degrade 1,3,5-TMB. Loss of 1,3,5-TMB in control was 
approximately $7.2 \pm 0.6 \%$. The results demonstrated that there were great differences between the biodegradability of two strains. Almost $3.1 \pm 0.3 \%$ of $1,3,5$-TMB was degraded by Staphylococcus sciuri strain A, while strain $\mathrm{C}$ was capable for degrading 1,3,5-TMB with degrees of $41.2 \pm$ $1.8 \%$.

\section{CONCLUSIONS}

Two indigenous bacteria for degrading of 1,3,5-TMB were isolated. Strains A and C, belonging to Staphylococcus sciuri and Micro bacterium schleiferi, respectively, are of particular interest because of their facultative anaerobic characteristics. The optimal $\mathrm{pH}$ and temperature was 7.0 and $30^{\circ} \mathrm{C}$ respectively. Mechanism of degradation and whether the bacteria could adapt to a wider range of temperature and $\mathrm{pH}$ need further study.

\section{REFERENCES}

[1] C. S. Harwood and J. Gibson, "Shedding light on anaerobic benzene ring degradation: a process unique to prokaryotes," Journal of bacteriology, vol. 179, pp. 301-309, 1997.

[2] J. Chen, X. Li, J. Li, Q. Zhao, C. Xu, and W. Shu, "Degradation of Environmental Endocrine Disruptor Di-2-Ethylhexyl Phthalate by a Newly Discovered Bacterium, Microbacterium Sp. Strain Cqo110Y," Applied microbial and cell physiology, vol. 74, pp 676-682, 2007.

[3] M. R. Fries, J. Zhou, J. Chee-Sanford, J. M. Tiedje, "Isolation, characterization, and distribution of denitrifying toluene degraders from a variety of habitats," Applied and Environmental Microbiology, vol. 8, pp. 2802-2810, 1994.
[4] J. F. Barker, G. C. Patrick, and D. Major, "Natural attenuation of aromatic hydrocarbons in a shallow sand aquifer," Ground Water Monitor Rev, vol. 7, pp. 64-71, 1987.

[5] S. M. Burland and E. A. Edwards, "Anaerobic benzene biodegradation linked to nitrate reduction," Appl Environ Microb, vol. 65 , no. 2 , pp. 529, 1999.

[6] E. A. Edwards, L. E. Wills, M. Reinhard, and D. Grbic-Galic, "Anaerobic degradation of toluene and xylene by aquifer microorganisms under sulfate-reducing conditions," Appl Environ Microb, vol. 58, no. 3, pp. 794, 1992.

[7] Y. Kasai, Y. Takahata, M. Manefield, and K. Watanabe, "Rna-based stable isotope probing and isolation of anaerobic benzene-degrading bacteria from gasoline-contaminated groundwater," Appl Environ Microbiol, vol. 72, no. 5, pp. 3586-3592, 2006.

[8] J. J. Alvarez Pedro, "Vogel timothy m. substrate interactions of benzene, toluene, and para-xylene during microbial-degradation by pure cultures and mixed culture aquifer slurries," Applied and Environmental Microbiology, vol. 10, pp. 2981-2985, 1991.

[9] D. R. Lovely, "Potential for anaerobic bioremediation of BTEX in petroleum-contaminated aquifers," Journal of Industrial Microbiology \& Biotechnology, vol. 18, pp. 75-81, 1997.

[10] R. Chakra borty and J. D. Coates, "Anaerobic degradation of mono aromatic hydrocarbons," Applied Microbiology and Biotechnology, vol. 64, pp. 437-446, 2004.

[11] E. Jindrova, M. Chocova, K. Demnerova, and V. Brenner, "Bacterial Aerobic Degradation of Benzene, Toluene, Ethyl benzene and Xylene," Folia Microbial (Praha), vol. 47, pp. 83-93, 2002.

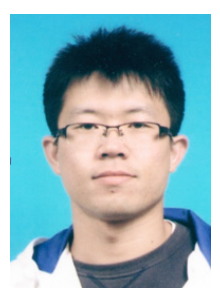

Lv Dunyu was born on March 2, 1984, China. He received China University of Geosciences (WUHAN) Doctor of Engineering, 2011. His major field of study is migration and transformation of new pollutants in vadose zone and groudwater. 